\title{
STATE-OF-THE-ART ON MONOLINGUAL LEXICOGRAPHY FOR BRAZIL (BRAZILIAN PORTUGUESE)
}

\section{Tanara ZINGANO KUHN}

Centre for General and Applied Linguistics Studies at University of Coimbra (CELGA-ILTEC)

Zingano Kuhn, Tanara: State-of-the-art on monolingual lexicography for Brazil (Brazilian Portuguese). Slovenščina 2.o, 7 (1): 98-112.

DOI: http://dx.doi.org/10.4312/slo2.0.2019.1.98-112.

This paper is a minireview of the current status of monolingual lexicography in Brazil. Firstly, a brief contextualization of the origins of Brazilian Portuguese dictionary-making is provided. Then, an account of contemporary monolingual dictionaries is given and a more detailed overview on print, digital, spelling, and school dictionaries is presented. Next, research into dictionary use is reviewed. Finally, the perception among the Brazilians with regards to corpora and use of crowdsourcing in lexicography is discussed.

Keywords: Brazilian lexicography, Brazilian Portuguese, monolingual dictionaries

\section{INTRODUCTION}

Portuguese is the official language in Angola, Brazil, Cape Verde, Guinea-Bissau, Equatorial Guinea, Mozambique, Portugal, São Tomé and Príncipe, and Timor-Leste. It is spoken by over 260 million people (Reto et al., 2016), with nearly 209 million people in Brazil alone (IBGE, 2018b). Over the course of the years, the language brought to Brazil in the $16^{\text {th }}$ century by its colonizer, Portugal, has changed due to significant influence of native indigenous, African, and immigrant languages (Perini, 2017), acquiring some particular characteristics in terms of phonology, morphology, syntax, lexicon, spelling and pragmatics (Baxter, 1992, p. 35). 
Despite these noticeable differences from European Portuguese, it was not until the $2 \mathrm{O}^{\text {th }}$ century that the first general monolingual dictionary fully encompassing Brazilian Portuguese came out: the Pequeno dicionário brasileiro da língua portuguesa (1938) (henceforth PDBLP), by Hildebrando de Lima e Gustavo Barroso, which is commonly considered the founding dictionary of the Brazilian lexicography (e.g., Krieger et al., 2006). This tremendously successful dictionary, according to Biderman (2003, p. 58, my translation), played a crucial role in the consolidation of the Brazilian Portuguese variety because "for the first time, it documented the linguistic norm of Brazil and its vocabulary". It should not be forgotten that, up until then, only dictionaries of Portuguese made in Portugal, hence, representing the European variety, were used in Brazil ${ }^{1}$. In other words, it is possible to say that the construction of the linguistic identity of Brazilian Portuguese, in the context of lexicography, started relatively late, especially if compared to other traditions.

\section{CONTEMPORARY MONOLINGUAL DICTIONARIES}

Monolingual lexicography in Brazil is mostly commercial, which is evidenced by the lengthy list of titles and the diversity of types that are currently available on the market. One interesting aspect to note is that paper books are the indisputable preferred format among publishers, especially for school dictionaries. In fact, publication of this type of dictionary has become a valuable business in the wake of a praiseworthy governmental programme, which purchases millions of volumes to be freely distributed to public schools. In the latest edition of the program (2012), 8.747.108 dictionaries were bought, at a cost of R\$ 93.335.743,18 (approximately 22.264.672,19 euros $^{2}$ ) (FNDE, 2017).

It should be noted that, despite this great variety of types of dictionaries of Portuguese, the lexicography of Brazil still lacks a dictionary for foreigners.

1 It is true that, starting in the $19^{\text {th }}$ century (especially after the independence of Brazil from Portugal, in 1822), complements to Portuguese dictionaries with "Brazilianisms", and dictionaries of regionalisms and technical/scientific terms appeared (Nunes, 2006). However, a fully-fledged monolingual dictionary of Brazilian Portuguese was only published much later, in the $20^{\text {th }}$ century. For further information on dictionaries used in Brazil before the $20^{\text {th }}$ century, see Biderman (2003), Finatto (1996) and Nunes (2006).

2 Based on the exchange rate of 19th April 2018. 


\subsection{Print general monolingual dictionaries}

According to Nunes (2004), in Brazil the image of a general monolingual dictionary strongly relies on the name of its author, unlike some European traditions, in which national institutes (Academias) or publishing houses often play that role. A look at the first column of Table 1, which informs the name by which dictionaries are usually referred to by Brazilians, reveals that they mostly correspond to the name/surname of the author.

At this point, it should be noticed that Table 1 shows the print general monolingual dictionaries of Brazilian Portuguese currently avaible on the market, with reference to their first edition and alternative formats, when they exist. Many dictionaries have had only one edition so far, while others have had more; in this case, only the latest edition is displayed. As will be seen, sometimes the same dictionary has a different name. This tends to refer to a new series, thus resetting the count of the number of editions.

Table 1: Contemporary print general monolingual dictionaries of Portuguese currently published in Brazil

\begin{tabular}{|c|c|c|c|c|c|c|c|}
\hline Known as & Year & $\begin{array}{l}\text { Edi- } \\
\text { tion }\end{array}$ & Name & Author(s) & $\begin{array}{l}\text { Publish- } \\
\text { er }\end{array}$ & Format(s) & Price \\
\hline \multirow[t]{3}{*}{ Aulete } & 1958 & $1^{\mathrm{st3}}$ & $\begin{array}{l}\text { Dicionário } \\
\text { contemporâ- } \\
\text { neo da língua } \\
\text { portuguesa }\end{array}$ & $\begin{array}{l}\text { Francisco } \\
\text { Júlio de } \\
\text { Caldas } \\
\text { Aulete }\end{array}$ & $\begin{array}{l}\text { Editora } \\
\text { Delta }\end{array}$ & \begin{tabular}{|l} 
Print \\
(5 volumes, \\
5500 pages)
\end{tabular} & $\begin{array}{l}\text { No longer } \\
\text { published. }\end{array}$ \\
\hline & $\begin{array}{l}2008 \\
\text { (web) }\end{array}$ & $1^{\mathrm{st} 4}$ & Aulete Digital & \multirow{2}{*}{$\begin{array}{l}\text { Paulo Gei- } \\
\text { ger (Ed.) }\end{array}$} & \multirow{2}{*}{$\begin{array}{l}\text { Lexikon } \\
\text { Editora }\end{array}$} & $\begin{array}{l}\text { Browser } \\
\text { based } \\
\text { Mobile app }\end{array}$ & Free \\
\hline & $\begin{array}{l}2011 \\
\text { (print) }\end{array}$ & $1^{\text {st5 }}$ & $\begin{array}{l}\text { Novíssimo } \\
\text { Aulete - dicio- } \\
\text { nário contem- } \\
\text { porâneo da } \\
\text { língua portu- } \\
\text { guesa }\end{array}$ & & & Print & $\mathrm{R} \$ 144.00$ \\
\hline
\end{tabular}

3 1st Brazilian edition. Due to the great success of this originally-Portuguese dictionary (1881, 1st edition), a decision was made to edit an adapted Brazilian version and to publish it simultaneously with the 4th Portuguese edition (Krieger et al., 2006; Nunes, 2008).

4 The first time it was published on-line as a browser-based resource. In 2007, it had been published as an executable for download.

5 The first edition of the general monolingual dictionaries as a paper book by Lexikon Publishers. 


\begin{tabular}{|c|c|c|c|c|c|c|c|}
\hline Known as & Year & $\begin{array}{l}\text { Edi- } \\
\text { tion }\end{array}$ & Name & Author(s) & $\begin{array}{l}\text { Publish- } \\
\text { er }\end{array}$ & Format(s) & Price \\
\hline \multirow[t]{3}{*}{ Aurélio } & 1975 & $1^{\text {st }}$ & $\begin{array}{l}\text { Novo Dicioná- } \\
\text { rio da Língua } \\
\text { Portuguesa }\end{array}$ & $\begin{array}{l}\text { Aurélio } \\
\text { Buarque } \\
\text { de Holan- } \\
\text { da Fer- } \\
\text { reira }\end{array}$ & $\begin{array}{l}\text { Nova } \\
\text { Fron- } \\
\text { teira }\end{array}$ & Print & $\begin{array}{l}\text { No longer } \\
\text { published }\end{array}$ \\
\hline & 2010 & $5^{\text {th }}$ & $\begin{array}{l}\text { Dicionário } \\
\text { Aurélio da } \\
\text { Língua Portu- } \\
\text { guesa } \\
\text { (1oo Anniver- } \\
\text { sary special } \\
\text { edition) }\end{array}$ & $\begin{array}{l}\text { Aurélio } \\
\text { Buarque } \\
\text { de Holan- } \\
\text { da Fer- } \\
\text { reira }\end{array}$ & Positivo & $\begin{array}{l}\text { Print with } \\
\text { CD-ROM } \\
\text { included }\end{array}$ & $\mathrm{R} \$ 250$ \\
\hline & 2014 & $\begin{array}{l}5^{\text {th }} \\
\text { (re- } \\
\text { print } \\
2010 \text { ) }\end{array}$ & $\begin{array}{l}\text { Dicionário } \\
\text { Aurélio da } \\
\text { Língua Portu- } \\
\text { guesa }\end{array}$ & $\begin{array}{l}\text { Aurélio } \\
\text { Buarque } \\
\text { de Holan- } \\
\text { da Fer- } \\
\text { reira }\end{array}$ & Positivo & $\begin{array}{l}\text { Print with } \\
\text { access key } \\
\text { to brows- } \\
\text { er-based } \\
\text { version }\end{array}$ & $\mathrm{R} \$ 429.90$ \\
\hline \multirow[t]{4}{*}{ Houaiss } & 2001 & $1^{\mathrm{st}}$ & $\begin{array}{l}\text { Dicionário } \\
\text { Houaiss da } \\
\text { Língua Portu- } \\
\text { guesa }\end{array}$ & $\begin{array}{l}\text { Antônio } \\
\text { Houaiss; } \\
\text { Mauro } \\
\text { Villar }\end{array}$ & Objetiva & $\begin{array}{l}\text { Print with } \\
\text { CD-ROM } \\
\text { included }\end{array}$ & $\begin{array}{l}\text { No longer } \\
\text { published }\end{array}$ \\
\hline & \multirow[t]{3}{*}{2009} & \multirow[t]{3}{*}{$2^{\text {nd }}$} & \multirow{3}{*}{$\begin{array}{l}\text { Dicionário } \\
\text { Houaiss da } \\
\text { Língua Portu- } \\
\text { guesa }\end{array}$} & \multirow{3}{*}{$\begin{array}{l}\text { Antônio } \\
\text { Houaiss; } \\
\text { Mauro } \\
\text { Villar }\end{array}$} & \multirow[t]{3}{*}{ Objetiva } & $\begin{array}{l}\text { Print with } \\
\text { CD-ROM }\end{array}$ & $\mathrm{R} \$ 309.90$ \\
\hline & & & & & & CD-ROM & $\mathrm{R} \$ 75.50$ \\
\hline & & & & & & $\begin{array}{l}\text { Brows- } \\
\text { er-based / } \\
\text { app }\end{array}$ & $\begin{array}{l}\text { For sub- } \\
\text { scribers only } \\
\text { (paid) } \\
\text { Cheapest } \\
\text { price/ } \\
\text { month: } \\
\text { UOL: } \\
\mathrm{R} \$ 19.90 \\
\text { Houaiss } \\
\text { Corporate: } \\
\text { R } \$ 75.00 \\
\text { (up to } 3 \\
\text { users) }\end{array}$ \\
\hline Sacconi & 2010 & $1^{\mathrm{st}}$ & $\begin{array}{l}\text { Grande Dicio- } \\
\text { nário Sacconi } \\
\text { da Língua Por- } \\
\text { tuguesa }\end{array}$ & $\begin{array}{l}\text { Luiz } \\
\text { Antônio } \\
\text { Sacconi }\end{array}$ & $\begin{array}{l}\text { Nova } \\
\text { Geração }\end{array}$ & $\begin{array}{l}\text { Print with } \\
\text { CD-ROM } \\
\text { included }\end{array}$ & $\mathrm{R} \$ 248.50$ \\
\hline
\end{tabular}




\begin{tabular}{|l|l|l|l|l|l|l|l|}
\hline Known as & Year & $\begin{array}{l}\text { Edi- } \\
\text { tion }\end{array}$ & Name & Author(s) & $\begin{array}{l}\text { Publish- } \\
\text { er }\end{array}$ & Format(s) & Price \\
\hline $\begin{array}{l}\text { Silveira } \\
\text { Bueno }\end{array}$ & 1972 & $1^{\text {st }}$ & $\begin{array}{l}\text { Dicionário da } \\
\text { Língua Portu- } \\
\text { guesa Silveira } \\
\text { Bueno }\end{array}$ & $\begin{array}{l}\text { Francisco } \\
\text { da Silveira } \\
\text { Bueno }\end{array}$ & $\begin{array}{l}\text { Editora } \\
\text { Forta- } \\
\text { leza }\end{array}$ & Print & $\begin{array}{l}\text { No longer } \\
\text { published }\end{array}$ \\
\cline { 2 - 7 } & 2015 & $2^{\text {nd6 }}$ & $\begin{array}{l}\text { Novo Dicioná- } \\
\text { rio da Língua } \\
\text { Portuguesa } \\
\text { Silveira Bueno } \\
\text { (+ 8o ooo } \\
\text { verbetes) }\end{array}$ & $\begin{array}{l}\text { Francisco } \\
\text { da Silveira } \\
\text { Bueno }\end{array}$ & $\begin{array}{l}\text { Difusão } \\
\text { Cultural } \\
\text { do Livro }\end{array}$ & Print & $\mathrm{R} \$ 80.91$ \\
\hline UNESP & 2004 & $1^{\text {st }}$ & $\begin{array}{l}\text { Dicionário } \\
\text { UNESP do } \\
\text { Português } \\
\text { Contemporâ- } \\
\text { neo }\end{array}$ & $\begin{array}{l}\text { Francisco } \\
\text { da Silva } \\
\text { Borba } \\
\text { (org.) }\end{array}$ & $\begin{array}{l}\text { UNESP } \\
\text { Editora }\end{array}$ & Print & $\mathrm{R} \$ 115$ \\
\hline---- & 2009 & $1^{\text {st }}$ & $\begin{array}{l}\text { Dicionário } \\
\text { Base Iracema } \\
- \text { Dicionário da } \\
\text { Lingua Portu- } \\
\text { guesa }\end{array}$ & $\begin{array}{l}\text { H. Maia } \\
\text { D'Oli- } \\
\text { veira }\end{array}$ & $\begin{array}{l}\text { PRI- } \\
\text {-Pris- } \\
\text { mática } \\
\text { Editora }\end{array}$ & Print & $\mathrm{R} \$ 224$ \\
\hline
\end{tabular}

Another relevant aspect to point out refers to the re-edition of almost all dictionaries (the exception is the UNESP) whose first edition was before 2009. This is because of the official implementation, in that year, of a long-existing spelling reform (the Acordo Ortográfico da Língua Portuguesa de 1990 ('The Portuguese Language Orthographic Agreement of 1990'), with the objective of the simplification and unification of spelling rules regulating the orthography in the Portuguese-speaking countries, as will be shown later.

Of all the seven dictionaries in Table 1, it is commonly assumed that the Aurélio and the Houaiss are popular references among the general public in Brazil. Special attention should be drawn to the Aurélio, as it is has been considered the de facto general monolingual dictionary of Brazil for many years due to the key role it played in the determination and fixation of the Brazilian linguistic norm (Biderman 2000, 2003; Finatto, 2006; Krieger et al., 2006; Nunes, 2004). It should not be forgotten that the Aurélio was authored by Aurélio Buarque de Holanda Ferreira, who had been one of the lexicographers of the famous PDBLP (mentioned at the outset) and used this first norm-setting

6 No information on the 1st edition of the Novo Dicionário da Língua Portuguesa Silveira Bueno (+ 8 o ooo verbetes). 
dictionary as the basis for his work. On the other hand, it is also important to remember that the Aurélio has been severely criticized by experts, who pointed out lack of lexicographical criteria (e.g., Biderman, 2000).

Also noteworthy is the UNESP, which is an important reference in the lexicography of Portuguese as it is the result of a rigorous academic project carried out at UNESP (State University of São Paulo, Araraquara), within a corpus-based framework. The organizer of this project, Francisco da Silva Borba, also coordinated other two dictionary projects following a corpus-based approach: the Dicionário de Usos do Português do Brasil (2002) and the Grande dicionário português do Brasil. The latter is said to have been submitted to the publisher in 2012, however, it has not come out yet, being only mentioned as "forthcoming" by some of its co-authors (e.g. Neves, 2012) and by the author himself in an interview in 2009 (Lopes, 2009).

\subsection{Digital general monolingual dictionaries}

The well-known digital revolution has had some impact on the publication of dictionaries in Brazil as well. This is not surprising, given that $64.7 \%$ of the people who are older than 10 years old uses the Internet (IBGE, 2018a). To go online, $94.6 \%$ of them prefer a mobile phone, $63.7 \%$ use a computer, and $16.4 \%$, a tablet (IBGE, 2018a).

One significant example of this impact is that another popular general monolingual dictionary, the Michaelis Dicionário Brasileiro da Língua Portuguesa (2015, Rosana Trevisan, editor; Melhoramentos Publishers), whose first print edition was in 1998, is no longer published as paper book. Its browser-based version is free, while its mobile app costs 12.99 euros.

Out of the dictionaries in Table 1, only Aulete, Aurélio and Houaiss are also available in digital format. Aulete has freely available website and mobile app. Aurélio can be accessed on a website by users who have bought its 2014 edition, which brings an access key. Houaiss online is also paid, since it is only available to subscribers of a paid Internet server and a corporate package, which includes other products such as a mobile app.

Frankenberg-Garcia (2017) showed that, despite the change of format - into both CD-ROM and website -, these dictionaries still follow the traditional 
Portuguese lexicography, which is meaning-driven. The same applies to those dictionaries that have apps. That indicates that most of the current lexicographic projects in Brazil only make superficial use of the radical possibilities offered by electronic media.

In addition to the electronic version of the traditional dictionaries mentioned so far, a number of digital dictionaries have been recently created that do not have the prestige of renown publishing houses, yet, apparently are widely used. The vast majority of novelties are available through mobile apps, however, most of them have very low lexicographic quality. With regard to browser-based monolingual general language dictionaries, some of the most popular are:

- https://www.dicio.com.br/

- https://dicionariodoaurelio.com/

- https://www.dicionarioinformal.com.br/

Dicio is published by 7 Graus, which is a content developer company that has the collaboration of three lexicographers, according to information provided in their website. Its mobile app version is highly popular, with a total of downloads between 1.000.000 and 5.000.000 on Google Play.

Despite its name, Dicionário do Aurélio is not the online version of the earlier mentioned and highly renown Aurélio. In fact, there is no information on who the author is, since the website only provides lookup results. It should be made clear that this is a product with very poor lexicographical base, which seems to indicate that this is a typical case of the use of a famous name as a click-bait.

The Dicionário Informal is available online and app for free. It is a collaborative dictionary in which users write the entries. According to the website, there is no process of validation by experts. Nevertheless, it is very popular among Brazilians.

Of all the browser-based dictionaries here mentioned, only Dicio and Dicionário Informal are website responsive when used in smaller screens, such as mobile phones. 


\subsection{Spelling dictionaries}

Portuguese spelling is determined by legally binding, state-sanctioned documents. Until recently, there were two official spelling norms, one for Brazilian Portuguese and the other, for European Portuguese, with the latter being also the norm for the other Portuguese-speaking countries. In order to help with the actual application of these spelling rules, it is the custom to compile vocabulários ('spelling dictionaries'). In Brazil, the Academia Brasileira de Letras (the Brazilian Language Academy) is responsible for making the Vocabulário Ortográfico da Língua Portuguesa (VOLP), with public funding.

As metioned earlier, the aim to have only one spelling rule regulating the orthography in all Community of Portuguese-speaking Countries (CPLP) led to an orthographic agreement - the Acordo Ortográfico da Língua Portuguesa de 1990 -, which was officially implemented in 2009. In addition, a decision was made to create a common spelling dictionary for all countries to support this orthographic reform: the Vocabulário Ortográfico Comum da Língua Portuguesa- VOC ('Common Spelling Dictionary of the Portuguese Language', Ferreira, Correia, \& Almeida (Orgs.), 2017).

VOC is the official reference for the orthography of Portuguese and was developed by a multinational team of lexicographers, under the coordination of the International Institute of the Portuguese Language (IILP), which is the official bureau for language policy of the CPLP. It is public funded and, as such, is freely available on an online platform.

The $5^{\text {th }}$ edition of VOLP (2009) is available in print, website and through an app. Whilst this edition is still used as a reference in Brazil, an updated version came out in 2017, integrated into VOC. According to Bechara (2017, my translation), "this edition of VOLP represents a significant advance in the Brazilian lexicography and, therefore, is of great importance as a safe source of consultation for specialists and for the general public."

\subsection{School dictionaries}

The Ministry of Education in Brazil funds the Programa Nacional do Livro e do Material Didático (PNLD) ('Textbook and Didactic Material National Programme'), which distributes free textbooks to students and dictionaries 
(the latter, since 2001) to public schools. The process of material acquisition involves a call for tenders, with publishers submitting their dictionaries, which then undergo systematic blind assessment by a team of experts. Only short-listed dictionaries are purchased. As mentioned at the outset, considering the size of Brazil and the great number of public schools, it is not surprising that making school dictionaries has become a major business.

Remarkably interesting is the fact that this profit-driven enterprise has had a major positive washback effect on the lexicography of Brazil. According to Krieger (2008), with the objective to promote the use of dictionaries as a key pedagogical resource in the process of learning, the PNLD has established selection criteria that include the definition of the lexicographical characteristics that are appropriate for each level of education. For that, a systematic and well-defined typology of school dictionaries was created (Table 2), being the first of its kind in Brazil. Given that for dictionaries to be short-listed for PNLD, they had to fully comply with these criteria, publishers promptly made the necessary changes, leading to certainly more qualified dictionaries.

Table 2 Typology of school dictionaries (Brasil, 2012; my translation)

\begin{tabular}{|c|c|c|}
\hline $\begin{array}{l}\text { Types of } \\
\text { dictionaries }\end{array}$ & $\begin{array}{l}\text { Level of educa- } \\
\text { tion }\end{array}$ & Characterization \\
\hline Type 1 & $\begin{array}{l}1^{\text {st }} \text { grade of ele- } \\
\text { mentary school }\end{array}$ & $\begin{array}{l}\text { - Minimum of } 500 \text { and maximum of } 1,000 \text { entries } \\
\text { - Lexicographic proposal adapted to the demands of the } \\
\text { initial literacy process. }\end{array}$ \\
\hline Type 2 & $\begin{array}{l}2^{\text {nd }} \text { to } 5^{\text {th }} \text { grade } \\
\text { of elementary } \\
\text { school }\end{array}$ & $\begin{array}{l}\text { - Minimum of 3,000 and maximum of } 15,000 \text { entries; } \\
\text { - Lexicographic proposal suitable for students in the consoli- } \\
\text { dation phase of the mastering of both writing skills and the } \\
\text { dictionary genre. }\end{array}$ \\
\hline Type 3 & $\begin{array}{l}6^{\text {th }} \text { to } 9^{\text {th }} \text { grade } \\
\text { of elementary } \\
\text { school }\end{array}$ & $\begin{array}{l}\text { - Minimum of } 19,000 \text { and maximum of } 35,000 \text { entries; } \\
\text { - Lexicographic proposal oriented by the characteristics of a } \\
\text { standard dictionary of school use, but adequate to students } \\
\text { of the last years of elementary school. }\end{array}$ \\
\hline Type 4 & $\begin{array}{l}1^{\text {st }} \text { to } 3^{\text {rd }} \text { grade of } \\
\text { secondary school }\end{array}$ & $\begin{array}{l}\text { - Minimum of } 40,000 \text { and maximum of } 100,000 \text { entries; } \\
\text { - Lexicographic proposal of a standard dictionary, but ade- } \\
\text { quate to the demands of secondary school, including voca- } \\
\text { tional school. }\end{array}$ \\
\hline
\end{tabular}

At this point, attention should be drawn to the fact that, among the list of the Type-4 dictionaries that were short-listed in the latest PNLD-dictionaries 
(Brasil, 2012: 97), there are two titles that were previously presented in the general monolinguals list (Table 1): the UNESP and the Novíssimo Aulete. While the latter is exactly the same dictionary, the UNESP purchased by the government was published in 2011, has a different publisher (Piá), and a slightly different number of entries (UNESP, 2004: 58.223 entries; UNESP, 2011: 58.237 entries). One interesting note is that this latest edition, unlike the original one from 2004, has been updated to the new orthography and is certainly popular, given that 290.690 issues were distributed to public schools all over Brazil.

Another significant element for fostering dictionary use in Brazil is the manual for teachers (Brasil, 2012), which has been especially developed and also freely distributed. It includes information on dictionaries (characteristics, purposes, expectations) and provides suggestions of activities for promotion and teaching of dictionary use.

Given all that has been shown, we can conclude that dictionary use is certainly encouraged in public schools in Brazil.

\section{RESEARCH ON DICTIONARY USE}

It has been often considered that the body of research on dictionary use in Brazil is relatively small. For instance, of the 320 empirical studies on dictionary use scrutinised in Welker (2010), only 30 (9.4\%) refer to dictionary use research that involves the Portuguese language, with the vast majority focusing on the foreign language of bilingual dictionaries. Nevertheless, some new light will be shed on this topic when the results of the European Survey on Dictionary Use - Brazil come out. Brazil was an external country in this major European-wide enterprise carried out with the support of European Network of e-Lexicography COST Action and, as such, also participated in this carefully-designed survey.

\section{CORPORA AND CROWDSOURCING (CITIZEN SCIENCE)}

In general terms, corpora tend to be dealt with in academy, indicating that the general public are not familiar with them. However, it is possible that this scenario changes in the future, considering the potential experience with corpora 
that might result from the proper use of the earlier mentioned teachers' manual created by PNLD (Brasil, 2012). Not only does this book provide teachers with explanation of what corpora are and their role in dictionary-making, it also proposes a creative activity for secondary students, promoting an interesting reflection on matters of sociolinguistics, in addition to dictionary use (Brasil, 2012, p. 76-77).

As mentioned earlier, the Dicionário Informal, which is a collaborative digital dictionary, is highly successful in Brazil, with hundreds of thousands of definitions sent and over a million app downloads. Such engaged participation suggests that the general public in Brazil is receptive to the idea of crowdsourcing in lexicography.

\section{CONCLUDING REMARKS}

Monolingual dictionaries play a crucial role in the legitimation of the linguistic identity of a nation. Although its relatively late start, the lexicography in Brazil has contributed significantly to the establishment and legitimization of Brazilian Portuguese as a variety with its own norms. Since the beginning, monolingual dictionaries have been very popular in Brazil, and nowadays there is about a dozen titles available both in print and digital formats, with a clear preference for paper books, especially for school dictionaries.

Although lexicography in Brazil is basically commercial-based, it cannot be forgotten that dictionary-making has been gradually increasing within academia. While these lexicographical projects are mostly public-funded and small, it is worth being attentive to their development, as they might bring forth promising new avenues for the area.

\section{ACKNOWLEDGEMENT}

This paper has been supported by the Coordination for the Improvement of Higher Education Personnel (Capes, Coordenação de Aperfeiçoamento de Pessoal de Nível Superior) - Brazil, through a PhD scholarship, process number 0973/13-0. 


\section{REFERENCES}

\section{Dictionaries and lexicographic resources:}

Academia Brasileira de Letras. Vocabulário Ortográfico da Língua Portugue$s a$ - VOLP (2009). $5^{\mathrm{a}}$ edição. São Paulo: Global.

Aulete Digital. Available at: http://www.aulete.com.br/

Barroso, G. and Lima, H. (1938). Pequeno dicionário brasileiro da língua portuguesa. Rio de Janeiro: Civilização Brasileira.

Bechara, E. (coord.) (2017). Vocabulário Ortográfico da Língua Portuguesa. 6. ${ }^{\mathrm{a}}$ edição. Rio de Janeiro: Academia Brasileira de Letras. Available at: http://voc.cplp.org/index.php?action=von\&von=br

Borba, F. da S. (2002). Dicionário de usos do português do Brasil. São Paulo: Ática.

Borba, F. da S. (2011). Dicionário UNESP do português contemporâneo. Curitiba: Piá.

Ferreira, J. P., Correia, M., and Almeida, G. de B. (orgs.) (2017). Vocabulário Ortográfico Comum da Língua Portuguesa. Praia: Instituto Internacional da Língua Portuguesa/Comunidade dos Países de Língua Portuguesa.

Michaelis Dicionário Brasileiro da Língua Portuguesa (2015). Rosana Trevisan (ed.). Melhoramentos Publishers. Available at: http://michaelis.uol.com. br [15 April 2018]

\section{Other:}

Baxter, A. (1992). Portuguese as a pluricentric language. In M. Clyne (ed.) Pluricentric languages: Differing norms in different nations. Berlin, New York: Mouton de Gruyter, pp. 11-43.

Biderman, M. T. C. (2000). Aurélio: sinônimo de dicionário? ALFA: Revista de Linguística, 44, 27-55.

Biderman, M. T. C. (2003). Dicionários do português: da tradição à contemporaneidade. $A L F A, 47(1), 53-69$.

Brasil. Ministério da Educação. Secretaria de Educação Básica (2012). Com direito à palavra: dicionários em sala de aula. [Elaboração: Egon Rangel]. Brasília: Ministério da Educação, Secretaria de Educação Básica. 
Finatto, M. J. B. (1996). Da lexicografia brasileira (1813-1991): a microestrutura dos dicionários gerais de língua. Linguística (ALFAL), 8, 53-87.

FNDE (2017). Programas do livro. Dados estatísticos. Available at:http://www.fnde. gov.br/programas/programas-do-livro/livro-didatico/dados-estatisticos [20 April 2018]

Frankenberg-Garcia, A. (2017). The lexicography of Portuguese. In: P. Hanks \& GM. de Schryver (eds) International Handbook of Modern Lexis and Lexicography. Springer, Berlin, Heidelberg https://doi.org/10.1007/978-3-6

IBGE (2018a). Acesso à internet e à televisão e posse de telefone móvel celular para uso pessoal : 2016. Rio de Janeiro. Available at: https://biblioteca.ibge. gov.br/index.php/biblioteca-catalogo?view=detalhes\&id=2101543 [15 April 2018]

IBGE (2018b). Projeção da população do Brasil e das Unidades da Federação. Available at: https://www.ibge.gov.br/apps/populacao/projecao/ [15 April 2018]

Krieger, M. da G. (2008). Políticas públicas e dicionários para escola: o Programa Nacional do Livro Didático e seu impacto sobre a lexicografia didática. Cadernos de Tradução, 2(18), 235-252.

Krieger, M. da G. (2012). O léxico do português do Brasil em dicionários. In T. Lobo, Z. Carneiro, J. Soledade, A. Almeida, \& S. Ribeiro (Eds.), Rosae: linguística histórica, história das línguas e outras histórias [online] (pp. 391-400): Salvador: EDUFBA. https://doi.org/10.7476/9788523212308

Krieger, M. da G., Müller, A. F., Garcia, A. R. da R., and Batista, R. P. (2006). O século XX, cenário dos dicionários fundadores da lexicografia brasileira: relações com a identidade do português do Brasil. ALFA, 5O(2), 173-187.

Lopes, R. J. (2009). A língua do Brasil, palavra por palavra. Unespciência, 26-29. Neves, M. H. de M. (2012). A análise funcionalista e o estabelecimento de quadros categoriais na gramática. Revista Estudos Linguísticos, 20(1), 99-117.

Nunes, J. H. (2004). Levantamento bibliográfico de dicionários brasileiros de língua portuguesa: uma interpretação discursiva. Estudos Lingüísticos XXXIII, 805-810.

Nunes, J. H. (2006). Dicionários no Brasil: análise e história do século XVI ao XIX. Campinas: Pontes

Nunes, J. H. (2008). Dicionário, sociedade e língua nacional: o surgimento dos dicionários monolíngües no Brasil (pp. 353-374): In I. S. Lima \& L. do Carmo (Eds.). História social da língua nacional. Rio de Janeiro: Edições Casa de Rui Barbosa. 
Perini, M. A. (2017). Gramática Descritiva do Português Brasileiro. Petrópolis, RJ: Vozes

PNLD - Programa Nacional do Livro e do Material Didático. Available at: http://portal.mec.gov.br/pnld/apresentacao

Reto, L.A., Machado, F.L., and Esperança, J.P. (2016). Novo atlas da língua portuguesa. Lisboa: Imprensa Nacional-Casa da Moeda.

Welker, H. A. (2010). Dictionary use: A general survey of empirical studies. Brasília: Author's Edition. 


\section{STANJE ENOJEZIČNE LEKSIKOGRAFIJE: BRAZILIJA}

Kratki znanstveni prispevek opisuje stanje enojezične leksikografije v Braziliji. Najprej na kratko predstavimo ozadje enojezične leksikografije za brazilsko portugalščino, nato pa predstavimo še sodobna enojezična slovarska dela, podrobneje pa se posvetimo tiskanim, digitalnim, pravopisnim in šolskim slovarjem. V nadaljevanju se osreodotočimo na leksikografske raziskave, ob koncu pa obravnavamo še odnos Brazilcev do korpusov in uporabe množičenja v leksikografiji.

Ključne besede: brazilska leksikografija, brazilska portugalščina, enojezični slovarji

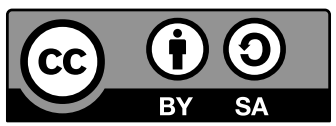

To delo je ponujeno pod licenco Creative Commons: Priznanje avtorstva-Deljenje pod enakimi pogoji 4.o Mednarodna. / This work is licensed under the Creative Commons Attribution-ShareAlike 4.o International.

https://creativecommons.org/licenses/by-sa/4.o/ 